\title{
Silica-poor, mafic alkaline lavas from ocean islands and continents: Petrogenetic constraints from major elements
}

\author{
Shantanu Keshav* and Gudmundur H Gudfinnsson \\ Geophysical Laboratory, Carnegie Institution of Washington, Washington DC 20015, USA. \\ *email:s.keshav@gl.ciw.edu
}

\begin{abstract}
Strongly silica-poor (ne-normative), mafic alkaline lavas generally represented by olivine nephelinites, nephelinites, melilitites, and olivine melilitites have erupted at various locations during Earth's history. On the basis of bulk-rock $\mathrm{Mg} \#$, high concentrations of $\mathrm{Na}_{2} \mathrm{O}, \mathrm{TiO}_{2}$, and $\mathrm{K}_{2} \mathrm{O}$, and trace element geochemistry, it has been suggested that these lavas represent low-degree melts that have undergone little crystal fractionation en route to the surface. Many of these lavas also carry highpressure mantle material in the form of harzburgite, spinel lherzolite, and variants of websterite xenoliths, and rare garnet-bearing xenoliths. However, phenocryst phases instead indicate that these magmas cooled to variable extents during their passage. We note subtle, yet important, differences in terms of $\mathrm{CaO}, \mathrm{Al}_{2} \mathrm{O}_{3}, \mathrm{CaO} / \mathrm{Al}_{2} \mathrm{O}_{3}$, and $\mathrm{CaO} / \mathrm{MgO}$. High-pressure experimental melting studies in $\mathrm{CMAS}-\mathrm{CO}_{2}(3-8 \mathrm{GPa})$ and natural lherzolitic systems $(3 \mathrm{GPa})$ demonstrate that at an isobar increasing $F$ leads to a moderate decrease in $\mathrm{CaO}+\mathrm{MgO}$, whereas $\mathrm{CaO} / \mathrm{MgO}$ and $\mathrm{CaO} / \mathrm{Al}_{2} \mathrm{O}_{3}$ sharply decrease. Relatively high $\mathrm{CaO} / \mathrm{Al}_{2} \mathrm{O}_{3}$ indicates melting in the presence of garnet $(\geq 85 \mathrm{~km})$. Studies also demonstrate that $\mathrm{CO}_{2}$-bearing lherzolitic systems, when compared with anhydrous ones, also have higher $\mathrm{CaO}$ content in the coexisting melt at a given $P$ and $T$. Comparison of the bulk-rock major-element chemistry of silica-poor, mafic alkaline lavas with experimentally determined high-pressure melts indicates that melting of anhydrous mantle lherzolite or garnet pyroxenite is not able to explain many of the major element systematics of the lavas. However, high-pressure partial melts of carbonated lherzolite have the right major element trends. Among ocean islands, lavas from Samoa and Hawaii are perhaps the products of very low degree of partial melting. Lavas from Gran Canaria and Polynesia represent products of more advanced partial melting. On continents, lavas from South Africa and certain localities in Germany are the products of a very low degree of partial melting, and those from Texas and certain other localities in Germany are products of a slightly more advanced degree of partial melting of a carbonated lherzolite. Lavas from Deccan, Czech Republic, and Freemans Cove are the products of even more advanced degree of partial melting. The mere presence of mantle xenoliths in some of these lavas does not necessarily mean that the erupted lavas represent direct mantle melts.
\end{abstract}

\section{Introduction}

Partial melting of upper mantle peridotite has been recognized as the primary source of basaltic lavas at mid-ocean ridges (MOR), ocean-island basalt localities, and those emplaced in parts of the continental crust (Basaltic Volcanism Study Project 1981). The upper mantle is heterogeneous as witnessed by the trace element and isotopic variability in mid-ocean ridge basalts (MORB) and ocean-island basalts (OIB; Zindler and Hart 1986). The bulk of the lavas at MOR is tholeiitic in composition and is characterized by the nearly complete absence of strongly to moderately silica under-saturated, primitive compositions (Dean Presnall 2004, Pers. Comm.). In

Keywords. Silica-poor lavas; partial melting; mantle lherzolite; garnet clinopyroxenite. 
contrast, a select few ocean islands and continental locations, besides hosting tholeiitic basalts, are also characterized by the ubiquitous presence of mafic alkaline lavas. Localities characterized by strongly to moderately silica under-saturated, relatively high $\mathrm{Mg} \#$ (bulk-rock), mafic alkaline lavas include Hawaii, Samoa, Polynesia, and Canary Islands among ocean islands, and India (Deccan), South Africa (Sutherland, Robertson, and Saltpetre Kop), Germany (Hegau, Urach, and Eifel), Oman, Czech Republic, France (Massif Central), Texas (Balcones province), and Canada (Freemans Cove) among the continents.

It has been suggested on the basis of high bulkrock $\mathrm{Mg} \#$, high concentrations of $\mathrm{Na}_{2} \mathrm{O}, \mathrm{TiO}_{2}$, and $\mathrm{K}_{2} \mathrm{O}$, and trace element geochemistry, that the aforementioned silica-poor lavas represent lowdegree melts, and are also derived from mantle melts that have undergone little crystal fractionation en route to the surface. Researchers have also proposed that the trace element and isotopic heterogeneity (mostly ascribed to the presence of garnet clinopyroxenite/eclogite) in silica-poor OIB (Hirschmann et al 2003; Kogiso et al 2003) is similar to such lavas emplaced in the continental crust (Hegner et al 1995; Janney et al 2002). On the basis of high-pressure partial melting experiments on garnet clinopyroxenite, this heterogeneity has also been proposed to correlate with the major element concentrations of the erupted basalts (Hirschmann et al 2003; Kogiso et al 2003). However, the possibility of garnet clinopyroxenite component, especially in the source of silica-poor OIB, remains controversial (Stracke et al 1999; Keshav et al 2004).

The silica-poor, mafic alkaline lavas, although volumetrically subordinate to tholeiitic lavas, are petrogenetically significant as many of them contain mantle xenoliths, making them likely candidates for near-primary magma compositions. In this contribution, we focus on the major-element chemistry of these silica-poor, high-Mg\# lavas from a few selected OIB and continental locations. For this purpose, some relevant questions we address are:

- Are there any systematic differences in majorelement chemistry of such lavas between (and possibly within) ocean islands and continents?

- On the basis of major-element chemistry and high-pressure melting experiments on anhydrous (Hirose and Kushiro 1993; Walter 1998) and carbonated (Hirose 1997; Gudfinnsson and Presnall 2003), fertile mantle lherzolite and recent studies on high-pressure melting of Mg-rich garnet clinopyroxenite (Hirschmann et al 2003; Keshav et al 2003a, b; Kogiso et al 2003; Keshav et al 2004), can the depth of segregation of these lavas be inferred?
- Can Mg-rich garnet clinopyroxenite, as suggested on the basis of trace element and isotope geochemistry, be a suitable source (along with mantle lherzolite) of these lavas in OIB and continental locations?

\section{Major element chemistry}

Silica-poor lavas comprising olivine-nephelinites, nephelinites, melilitites, and olivine-melilitites discussed here have been grouped according to their occurrence on ocean islands or in regions of continental crust. This division is warranted owing to different thicknesses of the lithosphere beneath continents and ocean islands in as much as this thickness controls the depth of primary magma generation and subsequent ponding and fractional crystallization.

In this paper, for individual localities in oceanisland settings and continental locations, chemical analyses of the rocks discussed have been taken from published literature. The data are not presented here in tabulated form, but are available from the authors upon request. The source(s) of these data are also presented in the figure captions. To facilitate comparison, $\mathrm{FeO}$ was adjusted so that $\mathrm{Fe}_{2} \mathrm{O}_{3} / \mathrm{FeO}=0.10 . \mathrm{Mg} \#$ is a conventional fractionation index, yet also an indicator of possible primary magma compositions. In this paper, we only discuss lavas with $\mathrm{MgO}$ contents greater than $10 \mathrm{wt} \%$. This arbitrary cutoff is mostly set to compare the chemical analyses of these lavas to those of the high-pressure partial melt compositions of appropriate mantle lithologies. In addition, among ocean islands and continents, glass compositions with $\sim 15 \mathrm{wt} \% \mathrm{MgO}$ have been reported only from the island of Hawaii (Clague et al 1995). These compositions are not alkalic, but are tholeiitic picrites. More importantly, in pseudo-ternary phase diagrams, these compositions show a clear and remarkable olivine controlled fractionation (Clague et al 1995).

Common phenocrysts in nephelinites and basanites are olivine, clinopyroxene, nepheline, spinel, and titanomagnetite. In melilititic lavas, olivine, melilite, calcite, perovskite, and sometimes phlogopite are common phenocrystic phases. However, of all the phases mentioned, olivine is the most dominant, and is often complexely zoned. For example, in Saltpetre Kop and Sutherland (South Africa) and also Deccan (Krishnamurthy et al 1999), phenocrystic olivine shows both normal and reverse zoning. In addition, clinopyroxene and spinel, although not commonly present as phenocrysts, also frequently exhibit complex zoning. This is especially true of spinels that commonly have an $\mathrm{Mg}-\mathrm{Cr}$ rich core and a rim that is richer in 


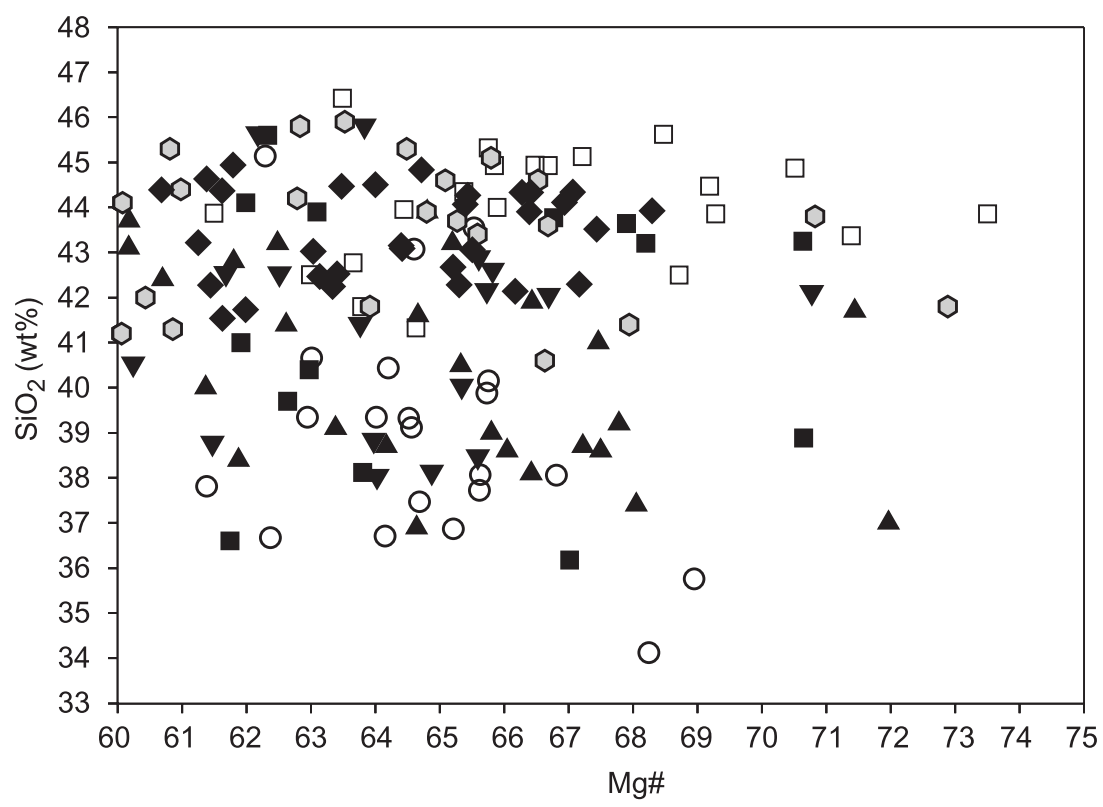

Figure 1. Bulk-rock $\mathrm{SiO}_{2}-\mathrm{Mg} \#$ plot of silica-poor, mafic alkaline lavas from a few selected ocean island localities. Data sources for figures 1-3 are: Gran Canaria (upright triangles - Hoernle and Schmincke 1993); HV, Oahu (blank circles Clague and Frey 1982); Koloa, Kauai (grey hexagons - Clague and Dalrymple 1987; upside down triangles - Maaloe et al 1992); Polynesia (blank squares - Dupuy et al 1989); Samoa (filled squares - Natland and Hawkins 1975).

$\mathrm{Al}, \mathrm{Fe}^{2+}, \mathrm{Fe}^{3+}$, and $\mathrm{Ti}$ (Boctor and Yoder 1986). Also, many of the olivine phenocrysts in these lavas are rimmed with spinel of varying composition. Thus, it appears that most of these lavas had a complex evolutionary history since their generation in their respective source regions. On the basis of this complexity, the bulk rock compositions of these lavas cannot necessarily be treated as liquid compositions.

\subsection{Ocean-Island settings}

Among ocean islands, the greatest degree of silica undersaturation is seen in lavas from Oahu (Clague and Frey 1982), Gran Canaria (Hoernle and Schmincke 1993), and some lavas from the island of Kauai (Clague and Dalrymple 1987; Maaloe et al 1992; figure 1). Among these lavas, $\mathrm{SiO}_{2}$ tends to increase as $\mathrm{Mg} \#$ decreases (figure 1). Lavas from Polynesia (Dupuy et al 1989) and Lihue Basin, Kauai (Reiners and Nelson 1998) do not appear to show these negative trends. Also, in figure 1 there appears to be quite a distinct boundary. This "boundary" separates lavas from Polynesia and Lihue Basin from Gran Canaria, Samoa (Natland and Hawkins 1975), and Oahu, and roughly lies at about $40-41 \mathrm{wt} \% \mathrm{SiO}_{2}$. It is worth noting that lavas from Koloa can be seen to fall into two separate categories. Distinct negative trends are seen in $\mathrm{CaO}-\mathrm{SiO}_{2}$ diagram (figure 2). However, in $\mathrm{CaO}-\mathrm{SiO}_{2}$ space, barring a few outliers, lavas from Samoa are clustered (figure 2). The "cutoff" at
40-41 wt\% $\mathrm{SiO}_{2}$ seen in figure 1 is also apparent in $\mathrm{CaO}-\mathrm{SiO}_{2}$ diagram (figure 2).

In a $\mathrm{CaO} / \mathrm{Al}_{2} \mathrm{O}_{3}-\mathrm{SiO}_{2}$ diagram (figure 3 ) also, lavas from ocean islands can be grouped on the basis of their undersaturation, as seen in figure 1. Lavas from Samoa, Lihue Basin (Kauai), Koloa (Kauai), and Polynesia have a tighter distribution compared to those from Gran Canaria and Oahu (figure 3 ).

\subsection{Continental locations}

$\mathrm{SiO}_{2}-\mathrm{Mg} \#$ relations in silica undersaturated lavas from the continents show more scatter (figure 4), however, trends are similar to those in OIB localities. Distinct negative trends can be seen among lavas from Freemans Cove, Balcones Province, Deccan, and Massif Central. At a given Mg\#, lavas from Urach, Saltpetre Kop, and Sutherland tend to be shifted toward lower $\mathrm{SiO}_{2}$ (wt\%). Distinctly negative trends are seen in $\mathrm{CaO}-\mathrm{SiO}_{2}$ (figure 5) diagram. At a given $\mathrm{SiO}_{2}$, lavas from Urach, Spiegel River, Sutherland, Balcones Province, and Saltpetre Kop are shifted toward higher $\mathrm{CaO}$ (figure 5).

Lavas from Oman, Deccan, and Czech Republic have the lowest $\mathrm{CaO}$. In the diagrams presented above, it appears that the major-element chemistry of lavas within Germany (Urach and Hegau) and South Africa are quite different, indicating that lavas in these localities may not be related by a common petrogenetic process. Similar trends are also seen in $\mathrm{CaO} / \mathrm{Al}_{2} \mathrm{O}_{3}-\mathrm{SiO}_{2}$ space (figure 6), 


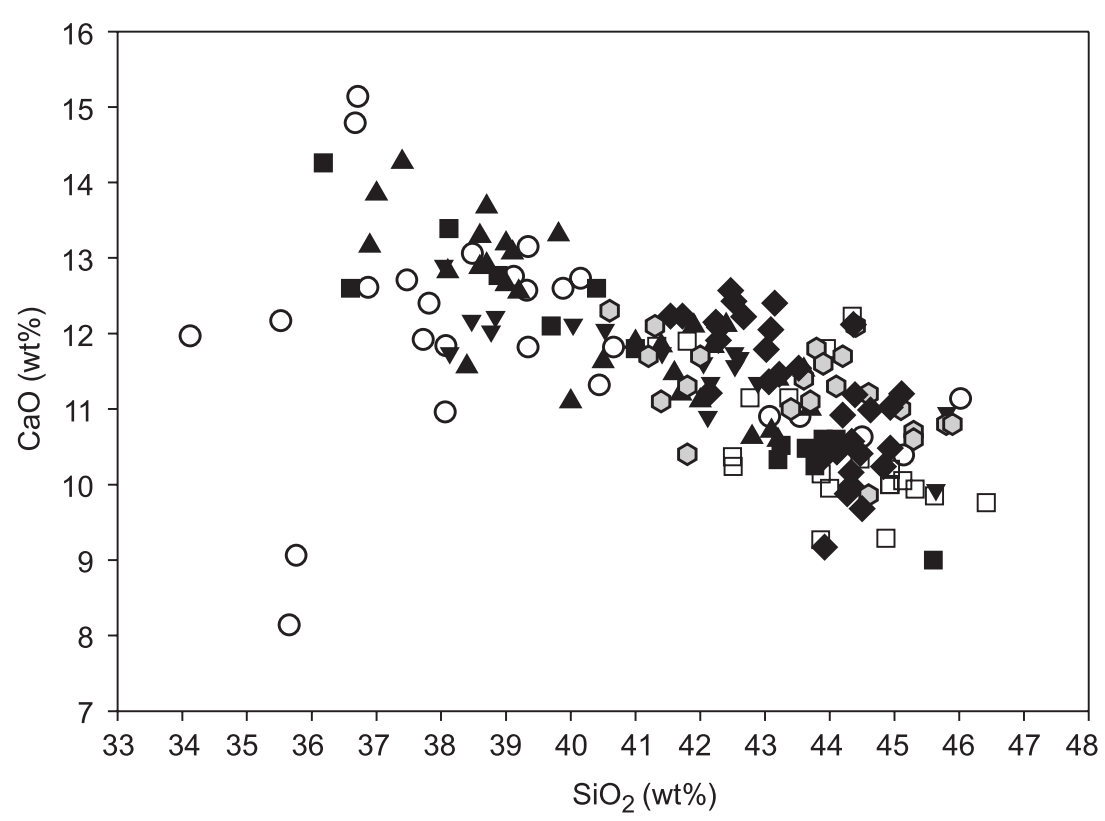

Figure 2. $\mathrm{CaO}-\mathrm{SiO}_{2}$ variation (bulk-rock) in lavas from the locations mentioned in figure 1.

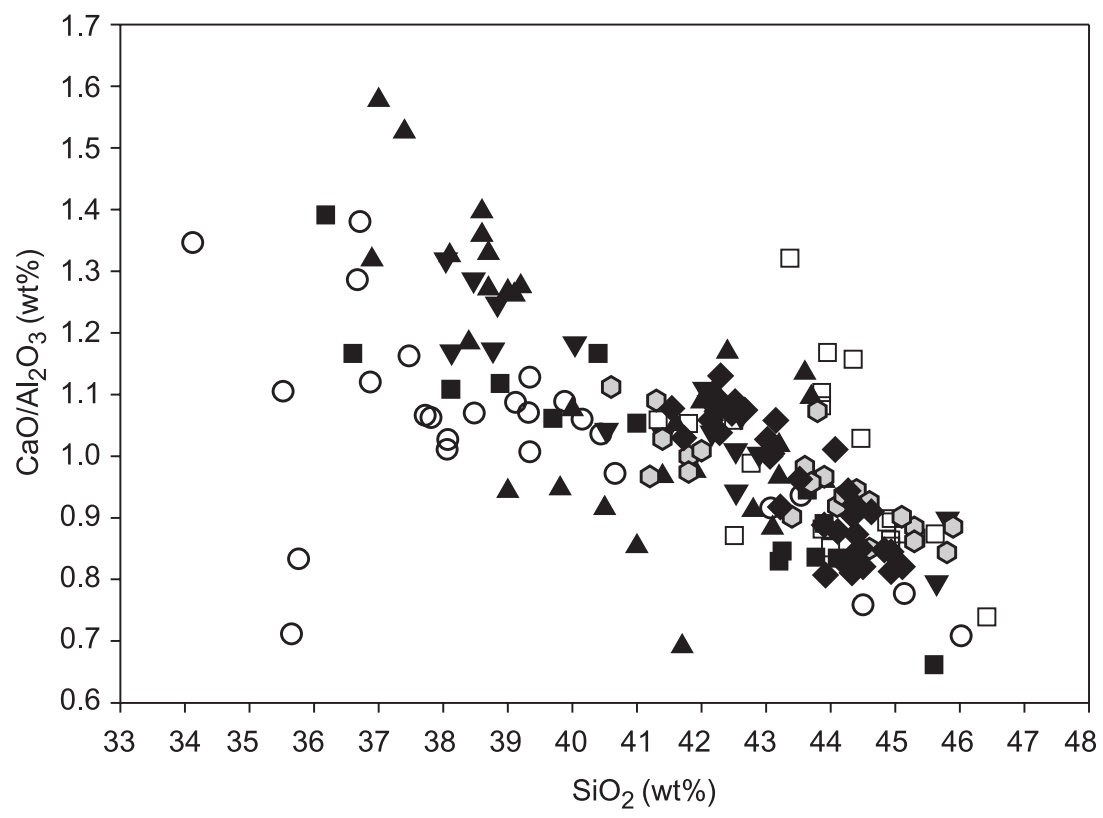

Figure 3. $\mathrm{CaO} / \mathrm{Al}_{2} \mathrm{O}_{3}-\mathrm{SiO}_{2}$ (bulk-rock) diagram for lavas in ocean-island localities.

data are less scattered, and well-defined negative trends are seen for almost all the lavas emplaced in the continental crust. At a given $\mathrm{SiO}_{2}$, lavas from Urach, Robertson, Sutherland, and Saltpetre Kop have the highest $\mathrm{CaO} / \mathrm{Al}_{2} \mathrm{O}_{3}$.

\section{Experimental constraints}

We now focus on a few high-pressure experimental melting studies on relevant mantle lithologies. Our purpose in doing so is not to provide a rigorous analysis of these studies, but to use them to put constraints on the petrogenesis of the lavas discussed. We briefly discuss experimental phase relations and melt compositions of:

- anhydrous model and natural lherzolite;

- carbonated model and natural lherzolite, and

- anhydrous high-Mg garnet clinopyroxenite.

We evaluate the origin of the silica-poor, relatively high-Mg\# lavas by comparing their major-element compositions with the partial melts produced in volatile-free (Hirose and Kushiro 1993; 


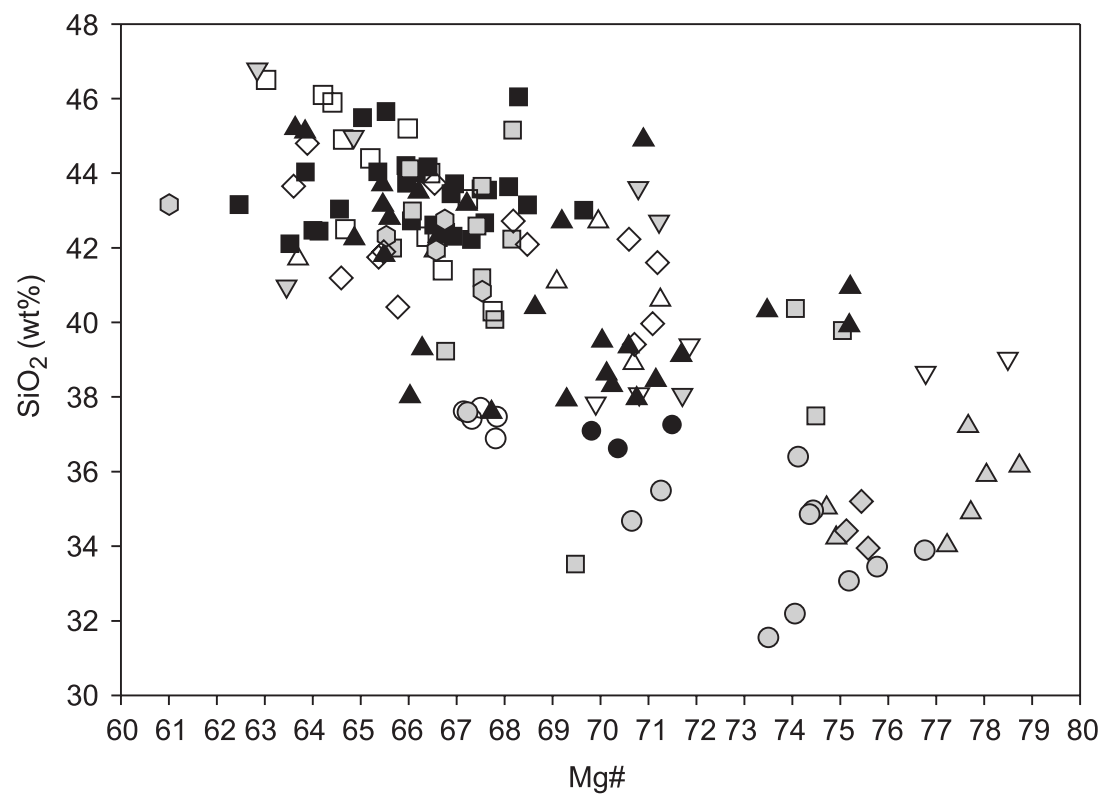

Figure 4. Bulk-rock $\mathrm{SiO}_{2}-\mathrm{Mg} \#$ plot of silica-poor, mafic alkaline lavas from a few selected continental locations. Data sources for figures 4-6 are: Czech Republic (grey squares - Vaneckova et al 1993); Germany (blank squares - Wedepohl et al 1994); Texas (upright filled triangles - Barker et al 1987); Massif Central (upside down filled triangles - Wilson and Downes 1991); Eifel (upright blank triangles), Hegau (upside down blank triangles, and Urach (upright grey triangles - Hegner et al 1995; Wilson et al 1995); Speidel River, S. Africa (filled circles), Robertson, S. Africa (blank circles), Sutherland, S. Africa (grey circles), and Saltpetre Kop, S. Africa (grey diamonds). All the data from S. Africa are from Janney et al 2002; Deccan (grey hexagons - Krishnamurthy et al 1999); Freemans Cove (blank diamonds - Mitchell and Platt 1984).

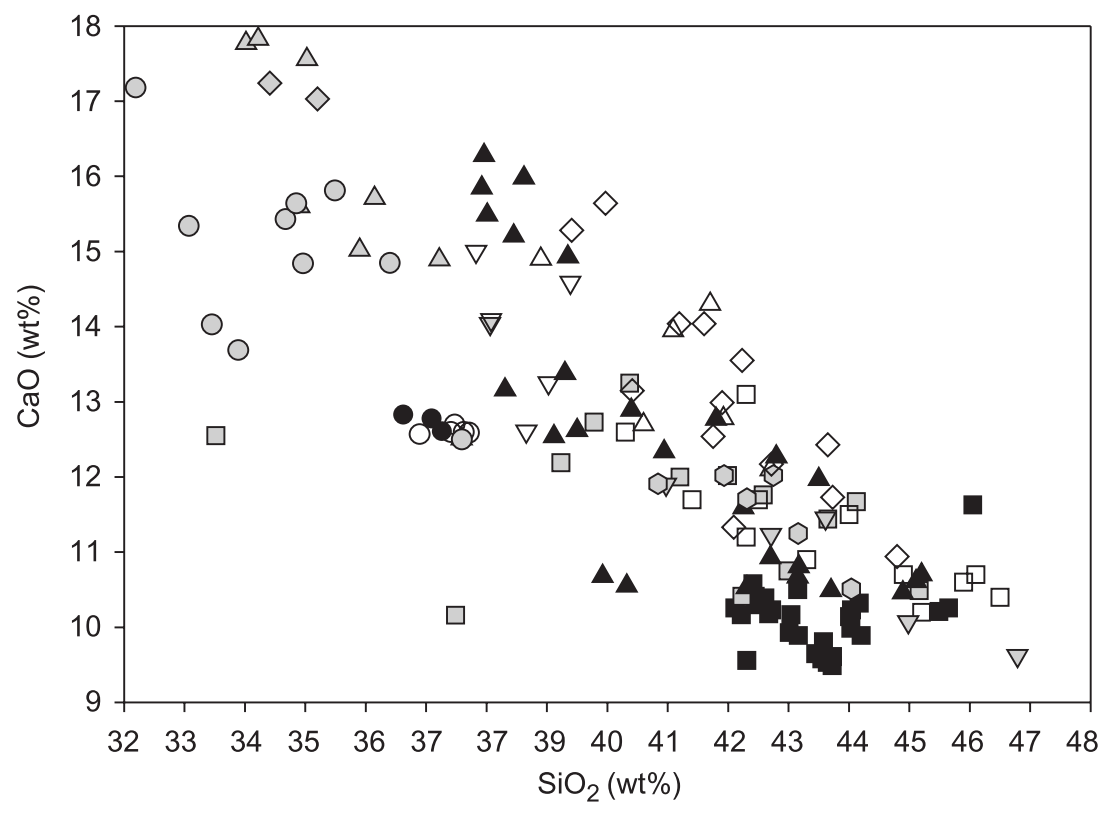

Figure 5. $\quad \mathrm{CaO}-\mathrm{SiO}_{2}$ variation (bulk-rock) in lavas from the locations mentioned in figure 4.

Walter 1998) and $\mathrm{CO}_{2}$-bearing (Ryabchikov et al 1993; Hirose 1997; Dalton and Presnall 1998a, b; Gudfinnsson and Presnall 2003) high-pressure melting experiments on lherzolite. It should be kept in mind that these are bulk-rock chemical analyses, and thus comparison with liquid compositions can lead to significant errors in the final petrogenetic interpretation. However, some key conclusions with respect to the petrogenesis of these lavas can still be drawn.

In addition, anhydrous basalt-lherzolite sandwich experiments (Kogiso et al 1998), and some 


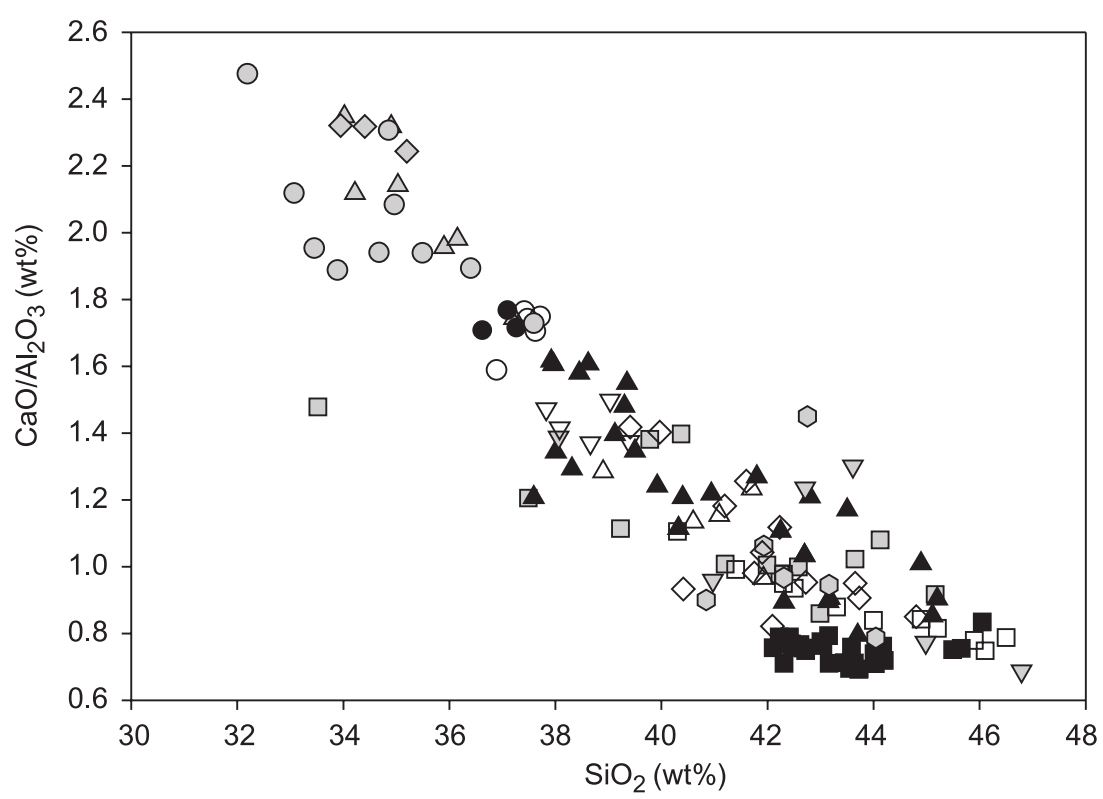

Figure 6. $\mathrm{CaO} / \mathrm{Al}_{2} \mathrm{O}_{3}-\mathrm{SiO}_{2}$ (bulk-rock) diagram for lavas in continental localities.

recent experiments on anhydrous, Mg-rich garnet clinopyroxenite (Keshav et al 2003 a, b; Keshav et al 2004) are also briefly discussed. To bring out some key major-element relations among natural lavas and experimental partial melts, we use $\mathrm{Na}_{2} \mathrm{O}+\mathrm{K}_{2} \mathrm{O}-\mathrm{SiO}_{2}$ (figures 7-8a), $\mathrm{MgO}$ $\mathrm{Al}_{2} \mathrm{O}_{3}$ (figures 7-8b), CaO-SiO 2 (figures 7-8c), and $\mathrm{CaO} / \mathrm{Al}_{2} \mathrm{O}_{3}-\mathrm{CaO}$ (figures $7-8 \mathrm{~d}$ ) as discriminant oxide (wt\%) diagrams.

\subsection{Anhydrous experiments}

High-pressure experimental melting studies on the phase relations of nominally anhydrous natural lherzolites (Hirose and Kushiro 1993; Walter 1998) and also simplified lherzolite in the system $\mathrm{CaO}-\mathrm{MgO}-\mathrm{Al}_{2} \mathrm{O}_{3}-\mathrm{SiO}_{2}$ (CMAS; Gudfinnsson and Presnall 1996; Milholland and Presnall 1998) have provided good insights into the generation of a variety of basaltic liquids. However, in natural lherzolite systems (which are high variance systems) quantitative information about phase relations at a very low (0.5-5\%) degree of melting is a challenge owing to severe quench modification of the run products and analytical difficulties. In contrast, in low-variance model lherzolite systems like CMAS (Gudfinnsson and Presnall 1996; Milholland and Presnall 1998), CMAS- $\mathrm{Na}_{2} \mathrm{O}$ (Walter and Presnall 1994), CMAS-FeO (Gudfinnsson and Presnall 2000), and CMAS- $\mathrm{CO}_{2}$ (Canil and Scarfe 1990; Dalton and Presnall 1998a, b; Gudfinnsson and Presnall 2003), accurate quantitative information about phase relations and melt compositions can be extracted with a large amount of melt present. Nevertheless, in anhydrous systems, it is observed that within the garnet-lherzolite stability field, the near-solidus melts are high in $\mathrm{CaO} / \mathrm{Al}_{2} \mathrm{O}_{3}$. With increasing pressure, these melts steadily become higher in $\mathrm{CaO} / \mathrm{Al}_{2} \mathrm{O}_{3}$ as $\mathrm{Al}_{2} \mathrm{O}_{3}$ decreases which is caused by the increasing stability of garnet (Gudfinnsson and Presnall 1996; Walter 1998). With an increasing degree of melting at an isobar in the garnet-lherzolite stability field, both $\mathrm{CaO} / \mathrm{Al}_{2} \mathrm{O}_{3}$ and $\mathrm{Al}_{2} \mathrm{O}_{3}$ decrease with a concomitant increase in the $\mathrm{MgO}$ content of the resulting melts (Walter 1998).

In addition, due to the progressively shrinking primary phase volume of olivine and increased compatibility of $\mathrm{Na}$ in clinopyroxene, with increasing pressure such melts also become more magnesian and alkali-poor. It is also seen that with increasing pressure in the garnet stability field, the amounts of $\mathrm{SiO}_{2}$ and $\mathrm{MgO}$ increase at the same time, leading to less picritic and more pyroxenitic melts (Gudfinnsson and Presnall 1996), whereas in the spinel stability field, the trend is steadily toward more picritic compositions with increasing pressure (Gudfinnsson and Presnall 1996; Gudfinnsson and Presnall 2000). In addition, nearsolidus melts of natural lherzolites are also relatively higher in alkalies $\left(\mathrm{Na}_{2} \mathrm{O}+\mathrm{K}_{2} \mathrm{O}\right)$ and $\mathrm{TiO}_{2}$ (Hirose and Kushiro 1993), and are thus strongly to moderately ne-normative.

\section{$3.2 \mathrm{CO}_{2}$-bearing experiments}

The high-pressure melting relations and melt compositions of carbonated lherzolite are drastically different from those of anhydrous lherzolite at low degrees of melting. The addition of $\mathrm{CO}_{2}$ in 
lherzolitic system makes a carbonate phase stable at the solidus. In natural (pyrolite- $\mathrm{CO}_{2}$; Falloon and Green 1989; Hirose 1997) and model upper mantle systems $\left(\mathrm{CMAS}^{-\mathrm{CO}_{2}}\right.$; Canil and Scarfe 1990; Dalton and Presnall 1998a, b; Gudfinnsson and Presnall 2003), this phase is dolomite (a solid solution between $\mathrm{CaCO}_{3}$ and $\left.\mathrm{CaMg}\left(\mathrm{CO}_{3}\right)_{2}\right)$ at pressures up to $3.5 \mathrm{GPa}$ and $4.8 \mathrm{GPa}$, respectively. Above these pressures and up to at least $8 \mathrm{GPa}$, dolomite is replaced by magnesite $\left(\mathrm{MgCO}_{3}\right)$ at the solidus (Dalton and Presnall 1998a; Gudfinnsson and Presnall 2003). The appearance of dolomite and magnesite at the solidus causes a reduction in the solidus of mantle lherzolite. This reduction is in the order of $\geq 250-300^{\circ} \mathrm{C}$ below the carbonatefree mantle solidus (Dalton and Presnall 1998a, b; Gudfinnsson and Presnall 2003), and it occurs because the melting temperatures of dolomite and magnesite are far below the solidus of the silicate phase assemblage.

Unlike in model lherzolite in the system CMAS$\mathrm{CO}_{2}$, where a systematic database exists on the high-pressure (2.8-8.0 GPa) melting relations and melt compositions (Canil and Scarfe 1990; Dalton and Presnall 1998a, b; Gudfinnsson and Presnall 2003), such studies in natural systems are rare. Rough phase relations and systematic melt compositions have been reported only in few studies (Falloon and Green 1989; Ryabchikov et al 1993; Hirose 1997). Those by Falloon and Green (1989) and Ryabchikov et al (1993) were conducted with a four-phase lherzolite assemblage, while the $\mathrm{CO}_{2}$-bearing melts reported by Hirose (1997) are mostly in the presence of a garnet-harzburgite assemblage. Owing to quench modification, Hirose (1997) did not report the near-solidus melt compositions.

The near-solidus melts of carbonated lherzolite are carbonatitic (Ryabchikov et al 1993; Dalton and Presnall 1998a, b; Gudfinnsson and Presnall 2003), grading into kimberlitic, melilititic, and perhaps nephelinitic, essentially exhibiting a continuum with increasing degree of melting (Hirose 1997; Gudfinnsson and Presnall 2003). The abovementioned transition can be divided into two separate pressure regimes. In the 2.5-4.0 GPa regime, the near-solidus melts are carbonatitic, but with increasing temperature, the melts become significantly more aluminous/siliceous and less magnesian (Gudfinnsson and Presnall 2003), resembling melilititic compositions. Gradation to kimberlitic melts does not occur at these pressures, as the melts are too aluminous and too low in $\mathrm{MgO}$ to be kimberlitic (Gudfinnsson and Presnall 2003). At pressures greater than about $4 \mathrm{GPa}$, the initial melts are carbonatitic, and with increasing degree of melting, they grade into kimberlitic melts. Thus, when compared with partial melts of anhydrous lherzolite these melts have low silica contents (but silica content increases away from the solidus, i.e., with increasing degree of melting), higher $\mathrm{CaO}$, and very low $\mathrm{Al}_{2} \mathrm{O}_{3}$ contents, and as a result, higher $\mathrm{CaO} / \mathrm{Al}_{2} \mathrm{O}_{3}$. The $\mathrm{CaO}$ content of these partial melts decreases dramatically with increasing degree of melting (Gudfinnsson and Presnall 2003). Using a natural spinel lherzolite with added $\mathrm{CO}_{2}$ as a starting composition, Ryabchikov et al (1993) determined melt compositions in equilibrium with four-phase peridotite at $5 \mathrm{GPa}$. At $1440^{\circ} \mathrm{C}$, the solidus melt in equilibrium with garnet lherzolite is carbonatitic, and similar to the 6-GPa partial melts of Dalton and Presnall (1998a). With increasing temperature above the solidus, Ryabchikov et al (1993) noted that the $\mathrm{SiO}_{2}$ and $\mathrm{MgO}$ contents of the melt increase and $\mathrm{CaO}$ concentration decreases, results that are in good agreement with those obtained in CMAS- $\mathrm{CO}_{2}$, and that the melts become more akin to kimberlite (Dalton and Presnall 1998a; Gudfinnsson and Presnall 2003). With increasing pressure from $3-8 \mathrm{GPa}$, the $\mathrm{CaO} / \mathrm{Al}_{2} \mathrm{O}_{3}$ ratio increases owing to increased stability of garnet in the solid residue (Gudfinnsson and Presnall 2003). In natural systems (Hirose 1997), at temperatures higher than the near-solidus melting interval at an isobar, the $\mathrm{FeO}^{*}$ and alumina contents remain approximately constant with increasing degree of melting. As can be seen from figures 7 and 8 , irrespective of pressure and degree of melting, the high-pressure partial melts of anhydrous lherzolite are quite different from those of carbonated lherzolite, while the trends are similar.

\subsection{Melting of Mg-rich garnet clinopyroxenite}

On the basis of trace element and isotope geochemistry of silica-poor, mafic alkaline lavas in oceanisland settings and continental locations, high-Mg eclogite/garnet pyroxenite has been proposed as a common source of introducing this heterogeneity into the source regions of these lavas (Hegner et al 1995; Janney et al 2002; Hirschmann et al 2003; Kogiso et al 2003). Attempts have also been made to relate this heterogeneity to the major element compositions of the erupted lava compositions (Hirschmann et al 2003; Kogiso et al 2003). In view of these propositions, a brief discussion of some recent high-pressure melting experiments on anhydrous high-Mg garnet pyroxenite is warranted. Three recent studies have addressed the high-pressure phase relations and melt compositions of high-Mg garnet pyroxenite (Hirschmann et al 2003; Kogiso et al 2003; Keshav et al 2004), and their possible role as source of magmas in OIB petrogenesis.

Hirschmann et al (2003) and Kogiso et al (2003) determined the phase relations and melt 
compositions of a mildly alkalic picrite starting composition at 2-7.5 GPa, and concluded on the basis of partial melt compositions, that high$\mathrm{Mg}$ garnet pyroxenite had the potential to be a source for OIB. Importantly, the alkalic to tholeiitic basalt transition observed in OIB was not bracketed in these two studies. Keshav et al (2004) determined the phase relations and melt compositions of a garnet-pyroxenite xenolith from Hawaii at 2-2.5 GPa. The composition of this xenolith resembles a tholeiitic picrite, and partial melts are strongly to moderately alkalic (ne-normative) in composition, at a moderate degree of melting. With increasing degree of melting, the melts become tholeiitic ( $h y$-normative), resembling the transition observed at OIB.

\section{Petrogenesis of silica-poor, mafic alkaline lavas}

\subsection{Oceanic regimes}

We now evaluate the origin of the lavas mentioned by comparing their major-element compositions with the experimental results. Figure 7(a) shows that the partial melts of garnet pyroxenite (Keshav et al 2004) are initially alkalic, smoothly crossing into the tholeiitic basalt field. Partial melts from two natural lherzolite starting mixes, labeled W (Walter 1998) and HK (Hirose and Kushiro 1993) are tholeiitic. However, we note that melts produced by very low degree of melting of these lherzolites could lie within the alkalic basalt field. The partial melts in lherzolite-basalt sandwich experiments (Kogiso et al 1998) at similar pressures are all alkalic, similar to the partial melts of garnet pyroxenite, and overlap the field of Polynesian and Hawaiian lavas. Partial melts of carbonated lherzolite (KLB-1) at $3.0 \mathrm{GPa}$ are alkalic to transitional (Hirose 1997), and do not appear to overlap any of the ocean-island basalts. Lavas from Samoa and Gran Canaria are different from almost all the experimental melts shown in figure 7, and there is partial overlap of Gran Canaria lavas with partial melts of sandwich experiments and garnet pyroxenite. However, low-degree melts of anhydrous lherzolite are also likely to overlap some of the Polynesian and Gran Canaria lavas. The partial melts of carbonated lherzolite (Hirose 1997) are distinct from the anhydrous lherzolite and garnet-pyroxenite derived melts in being richer in $\mathrm{MgO}, \mathrm{CaO}$, and alkalies, and poorer in $\mathrm{Al}_{2} \mathrm{O}_{3}$, $\mathrm{SiO}_{2}$ (figures $7 \mathrm{a}-\mathrm{d}$ ). Most noticeably, the partial melts of garnet pyroxenite are positively correlated in the $\mathrm{CaO}-\mathrm{SiO}_{2}$ and $\mathrm{MgO}-\mathrm{Al}_{2} \mathrm{O}_{3}$ (figures $7 \mathrm{~b}-\mathrm{c}$ ), and negatively correlated in $\mathrm{CaO} / \mathrm{Al}_{2} \mathrm{O}_{3}-\mathrm{CaO}$ diagrams (figure $7 \mathrm{~d}$ ), and thus transverse to the OIB trend. Partial melts from volatile-free lherzolite are distinct from OIB (figures $7 \mathrm{~b}-\mathrm{c}$ ), but as mentioned earlier, low to moderate degree melts of volatilefree lherzolite (Hirose and Kushiro 1993) mixed with those of carbonated lherzolite (Hirose 1997) are likely to completely overlap the OIB data. It further indicates that volatile-free melting of either lherzolite or garnet clinopyroxenite at the pressures of investigation cannot reproduce the OIB trend. The partial melting trends of garnet pyroxenite are completely opposite to the trends shown by the OIB lavas. These lavas are unlikely to have been produced by low degrees of melting of a lherzolite source in as much as the latter plot distinctly away from the Samoan and Polynesian lavas in figure $7(\mathrm{~b}, \mathrm{c})$.

Hawaiian lavas show a much wider spread that partially overlaps the partial melts of garnet pyroxenite, and extends toward the melts generated from carbonated lherzolite at 3.0 GPa (Hirose 1997). Although this observation suggests that the Hawaiian lavas require melt contributions from mixed sources (i.e., garnet clinopyroxenite and carbonated lherzolite), they could also be explained by mixing between carbonated and volatile-free lherzolite. The very Mg-rich nature of the partial melts of the carbonated lherzolite (figure $7 \mathrm{~b}$ ) can be explained by copious amounts of magnesite added in the starting mix. In $\mathrm{CaO}-\mathrm{SiO}_{2}$ (figure $7 \mathrm{c}$ ) and $\mathrm{CaO} / \mathrm{Al}_{2} \mathrm{O}_{3}-\mathrm{CaO}$ diagrams (figure $7 \mathrm{~d}$ ), the $3.0 \mathrm{GPa}$ partial melts of carbonated lherzolite (Hirose 1997) not only show the OIB trends, good overlap is also observed, again indicating that $\mathrm{CO}_{2}$ appears to be a required component in the generation of the silica-poor ocean-island basalts considered here. This overlap does not indicate that the bulk-rock compositions considered can necessarily be treated as liquid compositions.

It is imperative to mention that in the absence of high-pressure experimental data on garnet clinopyroxenite melting in the presence of $\mathrm{CO}_{2}$, we cannot evaluate whether OIB lavas could be produced by such source(s). Alternatively, the OIB trends could potentially be produced by varying degrees of melting of $\mathrm{CO}_{2}$-bearing lherzolite (possibly with variable geotherms; Gudfinnsson and Presnall 2003). It is important to note that the experimental data from melting of volatile-free garnet lherzolite (Hirose and Kushiro 1993; Walter 1998) do not extend to the low degrees of melting likely to be relevant to the generation of OIB. Experimental data at lower pressures (Walter and Presnall 1994) indicate that such melts could be alkalic in the 3.0-4.0 GPa pressure range. One problem with this model is the high $\mathrm{MgO}$ content of the partial melts of carbonated peridotite compared to compositions of OIB. Possible explanations for this discrepancy include, firstly, that crystal fractionation 

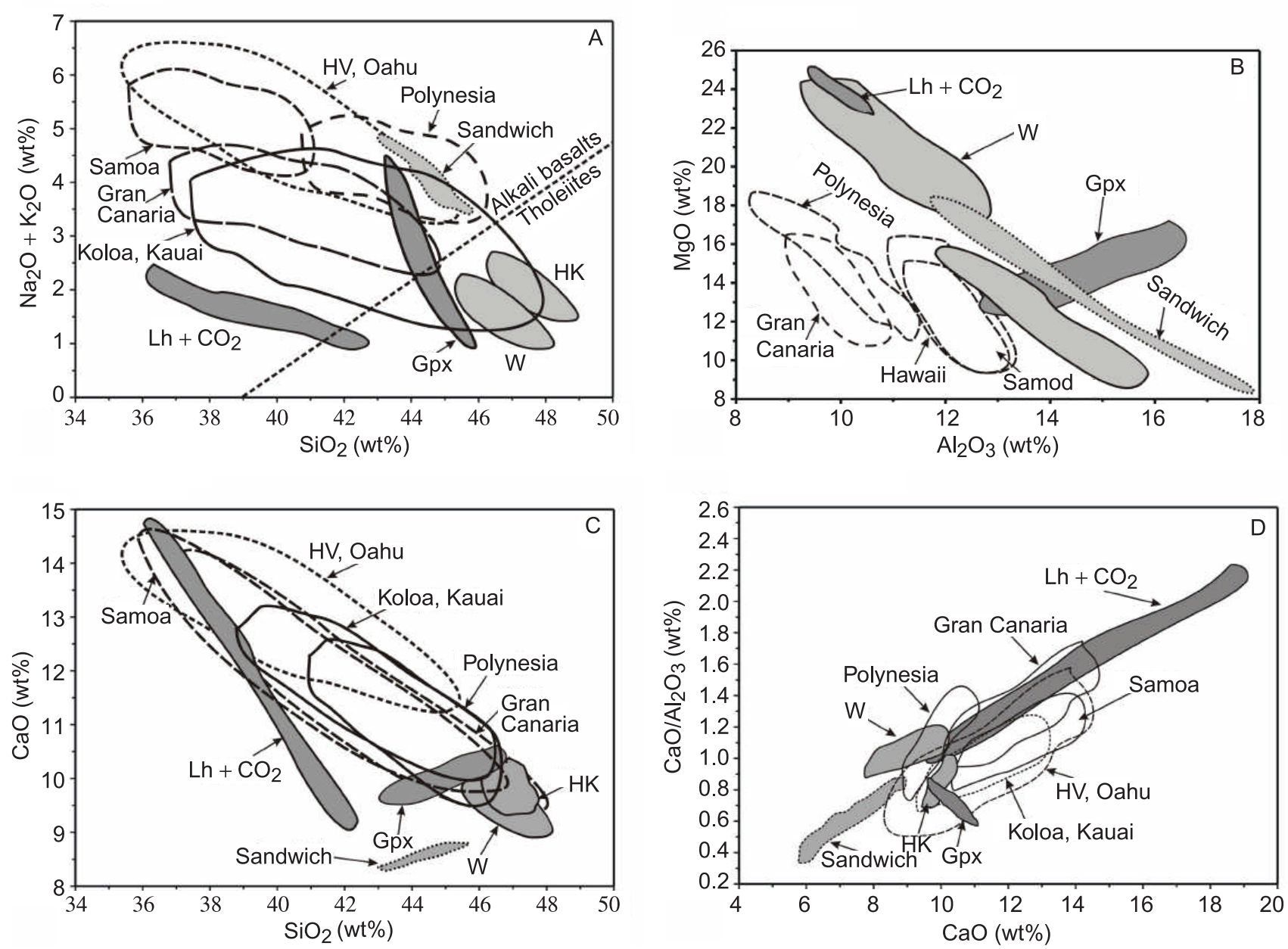

Figure 7. Major element compositions of silica-poor, mafic alkaline lavas from ocean islands compared to experimentally produced partial melt compositions in terms of (a) $\mathrm{Na}_{2} \mathrm{O}+\mathrm{K}_{2} \mathrm{O}-\mathrm{SiO}_{2}$; (b) $\mathrm{MgO}_{-} \mathrm{Al}_{2} \mathrm{O}_{3}$; (c) $\mathrm{CaO}_{-} \mathrm{SiO}_{2}$, and (d) $\mathrm{CaO} / \mathrm{Al}_{2} \mathrm{O}_{3}-\mathrm{CaO}$. Abbreviations are: $\mathrm{Lh}+\mathrm{CO}_{2}$, partial melts of carbonated peridotite (Hirose 1997 ); $\mathrm{HK} \& \mathrm{~W}$ are partial melt compositions of anhydrous lherzolite at 2.0-3.0 GPa (Hirose and Kushiro 1993), and 3.0-4.0 GPa (Walter 1998), respectively; Gpx, partial melting trend of garnet pyroxenite (Keshav et al 2004). Field labeled "Lh + basalt sandwich" refers to partial melt compositions of basalt-lherzolite sandwich experiments (Kogiso et al 1998).

causes the compositions of erupted OIB lavas to become considerably less magnesian than their primary magmas, and, secondly, that the experimentally produced $\mathrm{CO}_{2}$-bearing melts (Hirose 1997) are highly magnesian because of the large amount of magnesite added to the starting composition, which notably led to the exhaustion of clinopyroxene at a low degree of melting.

Thus, from the discussion above, we note that although the partial melt compositions of anhydrous mantle lherzolite have the right trends when compared to natural lavas, these partial melts do not extend to the extreme degree of undersaturation observed in natural lavas. Also, the melting of Mg-rich garnet clinopyroxenite of the right bulk composition traces the alkalic to tholeiitic basalt transition in ocean islands (Keshav et al 2004), but in major-element composition space the high-pressure partial melting trends are transverse to those seen in natural lavas. On the basis of this observation, a significant contribution of garnet clinopyroxenite of the chosen bulk composition can perhaps be dismissed as dictating the major-element budget of silica-poor, mafic alkaline ocean-island basalts. In addition, even though trace element and isotope geochemistry studies suggest involvement of subducted oceanic crust of various bulk compositions (Michael Bizimis 2004, Pers. Comm.), and mixing of lherzolitic and pyroxenitic sources, mixing of melts of these lithologies does not produce the right major-element trends seen in natural lavas. However, by comparing the high-pressure partial melt compositions of a natural carbonated lherzolite at $3 \mathrm{GPa}$ (Hirose 1997) with those in CMAS- $\mathrm{CO}_{2}$ at 3-8 GPa (Gudfinnsson and Presnall 2003) and natural lavas, we make a clear and convincing case that the high-pressure partial melt compositions of carbonated lherzolite 

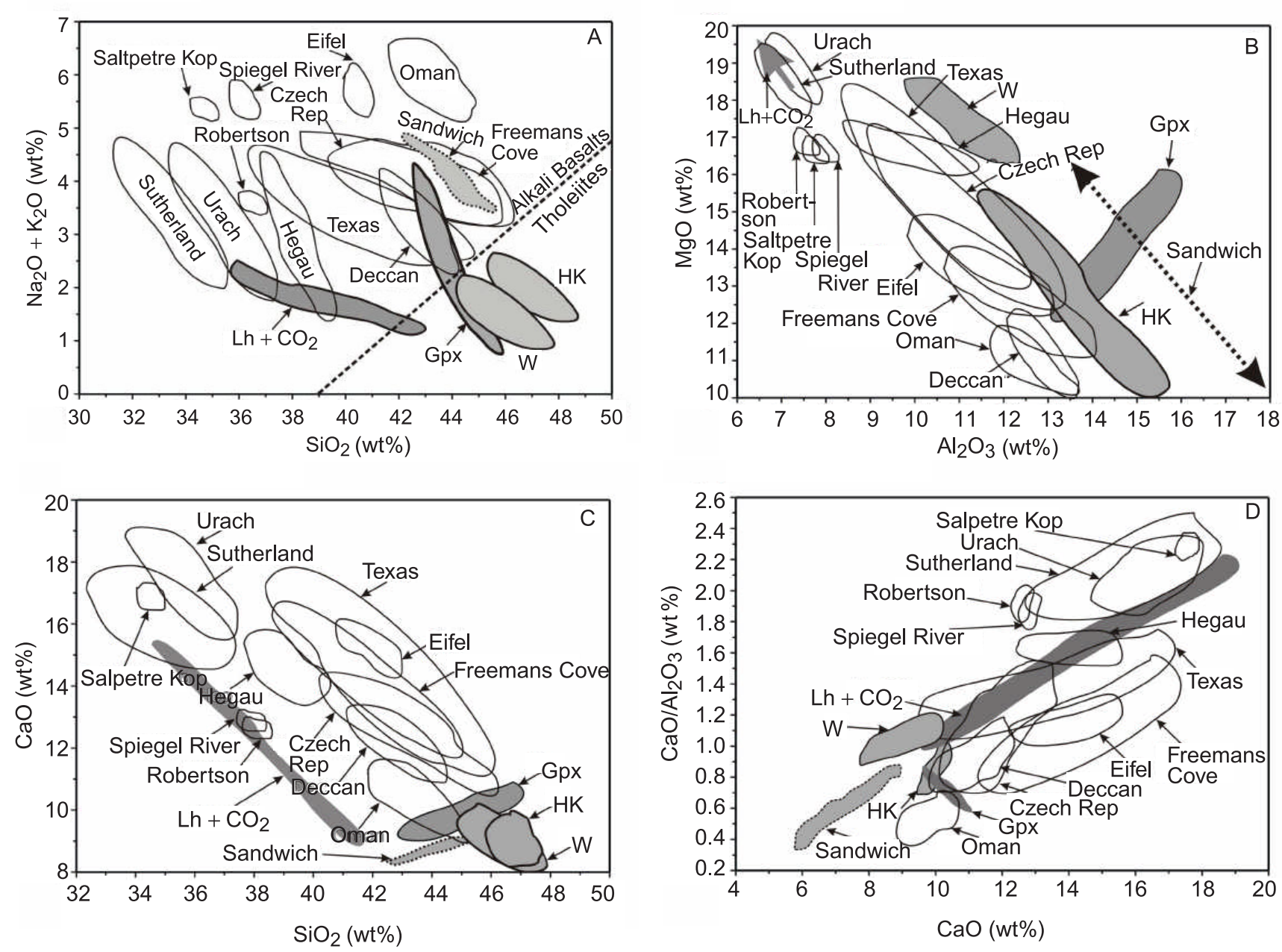

Figure 8. Major element compositions of silica-poor, mafic alkaline lavas from continental locations compared to experimentally produced partial melt compositions in terms of (a) $\mathrm{Na}_{2} \mathrm{O}+\mathrm{K}_{2} \mathrm{O}-\mathrm{SiO}_{2}$; (b) $\mathrm{MgO}-\mathrm{Al}_{2} \mathrm{O}_{3} ;$ (c) $\mathrm{CaO}-\mathrm{SiO}_{2}$, and (d) $\mathrm{CaO} / \mathrm{Al}_{2} \mathrm{O}_{3}-\mathrm{CaO}$. Abbreviations are: $\mathrm{Lh}+\mathrm{CO}_{2}$, partial melts of carbonated peridotite (Hirose 1997 ); $\mathrm{HK} \& \mathrm{~W}$ are partial melt compositions of anhydrous lherzolite at 2.0-3.0 GPa (Hirose and Kushiro 1993), and 3.0-4.0 GPa (Walter 1998), respectively; Gpx, partial melting trend of garnet pyroxenite (Keshav et al 2004). Field labeled "Lh + basalt sandwich" refers to partial melt compositions of basalt-lherzolite sandwich experiments (Kogiso et al 1998).

not only have the right trends as seen in natural lavas, but in many cases the overlap among these two is remarkable.

\subsection{Continental areas}

Compared to OIB, major-element composition of lavas on continents show a wide variation, and this is especially true of their alkali contents (figure 8a). Although with different slopes, these lavas have negative correlations in the $\mathrm{Na}_{2} \mathrm{O}+\mathrm{K}_{2} \mathrm{O}-$ $\mathrm{SiO}_{2}$ diagram (figure 8a). In continental locations, lavas from within Germany (Eifel, Hegau, and Urach) and South Africa (Saltpetre Kop, Sutherland, Robertson, and Spiegel River) appear to be different from each other. For example, lavas in Urach and Hegau show similar spread with quite similar total alkalies. However, lavas from Hegau are shifted toward slightly higher silica contents. On the other hand, lavas from Eifel are richer in total alkalies, and also have a limited range in composition. It appears that Eifel lavas may not be derived from any known process of fractionation from lavas parental to Urach/Hegau. It is possible however that the extension of very low-degree partial melts of garnet pyroxenite (Keshav et al 2004) may intersect the compositional field of Eifel lavas. High-pressure partial melting of anhydrous mantle lherzolite appears to be incapable of explaining the compositional range shown in figure 8(a). Similarly, lavas from Sutherland appear to be unrelated to those in Robertson, Saltpetre Kop, and Spiegel River. Lavas from Texas, Deccan, Czech Republic, and Freemans Cove partially overlap the 
compositional field encompassed by high-pressure partial melts of garnet pyroxenite (Keshav et al 2004), an extension of low-degree partial melts of anhydrous lherzolite (Hirose and Kushiro 1993; Walter 1998), and also basalt-lherzolite experiments (Kogiso et al 1998). Partial melts of carbonated lherzolite at $3 \mathrm{GPa}$ (Hirose 1997), although with very shallow slope, also partially overlap the compositional field of lavas from Hegau, Urach, and Sutherland.

The compositional diversity seen in figure 8(a) seems to disappear in $\mathrm{MgO}-\mathrm{Al}_{2} \mathrm{O}_{3}$ (figure 8b), $\mathrm{CaO}-\mathrm{SiO}_{2}$ (figure 8c), and $\mathrm{CaO} / \mathrm{Al}_{2} \mathrm{O}_{3}-\mathrm{CaO}$ (figure $8 \mathrm{~d}$ ) diagrams. Of all the locations considered here, lavas from Deccan, Czech Republic, Oman, and Freemans Cove are the least magnesian and also the most aluminous, and compositionally closer to the partial melts of anhydrous lherzolite (Hirose and Kushiro 1993). Among lavas from Germany, those from Urach are the most magnesian and also the least aluminous, followed by Hegau, and then Eifel, essentially exhibiting a rough continuum. Interestingly, in the $\mathrm{MgO}-$ $\mathrm{Al}_{2} \mathrm{O}_{3}$ diagram (figure 8b), lavas from all the South African localities also exhibit a continuum, with those from Sutherland being the most magnesian and the least aluminous, and those from Saltpetre Kop, Robertson, and Spiegel River overlapping with each other. As seen in the case of OIB, the partial melts of garnet pyroxenite are clearly transverse to the trend shown also by the lavas from various continental locations. Similar arguments can be extended to $\mathrm{CaO}-\mathrm{SiO}_{2}$ (figure $8 \mathrm{c}$ ) and $\mathrm{CaO} / \mathrm{Al}_{2} \mathrm{O}_{3}-\mathrm{CaO}$ (figure $8 \mathrm{~d}$ ) relations among experimental melts of carbonated/anhydrous lherzolites and lava compositions. In almost all the diagrams with major element oxides considered here, partial melts of carbonated lherzolite appear to have the right trends to explain the variation seen in the continental lavas. This is especially true for $\mathrm{MgO}-\mathrm{Al}_{2} \mathrm{O}_{3}, \mathrm{CaO}-\mathrm{SiO}_{2}$, and $\mathrm{CaO} / \mathrm{Al}_{2} \mathrm{O}_{3}$ $\mathrm{CaO}$. In addition, the compositional spectrum seen in partial melts of carbonated lherzolite at $3 \mathrm{GPa}$ appears to overlap with that of lavas from various locations. On this basis, it appears that lavas from Deccan, Czech Republic, Oman, and Freemans Cove are products of relatively high degree of partial melting. With gradually decreasing degree of partial melting and increasing $\mathrm{CO}_{2}$ content of the melt, a compositional spectrum resembling that of lavas from Eifel, Hegau, Spiegel River, Robertson, Sutherland, Urach, and Saltpetre Kop is seen. It should be noted that although the partial melts of carbonated lherzolite do not directly overlap those seen in lavas, we note that these differences may all be due to the restricted nature of starting mixes used in the experiments.

\subsection{A note on Deccan}

The Deccan Volcanic Province in west central India has an areal extent of $\sim 800,000 \mathrm{~km}^{2}$ (Watts and Cox 1989). The lava pile attains a maximum thickness of over $2 \mathrm{~km}$ in the western part of the outcrop area and thins to 200 meters at the eastern, northern, and southern fringes (Kaila et al 1981). Volcanism began in the mid to late Cretaceous when greater India broke away from Madagascar (Sclater and Fisher 1974). The peak of magmatism coincides with the separation of the Seychelles and the Mascarene Plateau from western India around 60 $65 \mathrm{Ma}$ (Norton and Sclater 1979). At this time, the western margin of the Indian subcontinent, and especially the Kutch area appears to have been near or over the proposed thermal anomaly near Reunion.

In Kutch, the Deccan traps are confined to a long strip bordering the Mesozoic highlands from Lakhpat on the northwest to Anjar in the east (Biswas and Deshpande 1973). The alkali basalts in Kutch, the focus of this section, are nowhere in contact with the Deccan tholeiites, but several lines of evidence suggest a close relationship. Available ${ }^{40} \mathrm{Ar} /{ }^{39} \mathrm{Ar}$ dates place the Deccan volcanism between 69 and $64 \mathrm{Ma}$ (Venkatesan et al 1986). Duncan and Pyle (1988) and Courtillot et al (1986) have bracketed the entire eruption within a time span of just $1 \mathrm{Ma}$, with a mean age of $65 \mathrm{Ma}$. However, ${ }^{40} \mathrm{Ar} /{ }^{39} \mathrm{Ar}$ ages for the alkali basalts range between $64.4 \pm 0.6$ and $67.7 \pm 0.7 \mathrm{Ma}$, suggesting a span of $\sim 3 \mathrm{Ma}$ for the alkaline magmatism. One of the alkali basalts from Dharam Hill gives an age of $68 \pm 2 \mathrm{Ma}$ (Venkatesan et al 1986), while the tholeiitic basalts outcropping in the same region yield an age of $66.8 \pm 0.3 \mathrm{Ma}$. The overlap in age suggests a close association between these two types of magmatism in Kutch (Pande et al 1989). Their genetic relationship is also documented by $\mathrm{Sr}$ and Nd isotopic data, which suggests a common source (Pande et al 1989). The Kutch alkaline volcanics thus are spatially and temporally correlated with the Deccan basalts. The alkalic lavas considered here are special because they have brought a suite of mantle xenoliths. Most of these ultramafic xenoliths are found in the alkalic lavas of Bhujia, Dongar, and Dhrubia (Karmalkar et al 2000).

Lately, more complications have been introduced into the debate over the total duration of the volcanism in Deccan. Basu et al (1993) dated some alkaline rocks in northern Deccan providing ${ }^{40} \mathrm{Ar} /{ }^{39} \mathrm{Ar}$ ages of $\sim 68.5 \mathrm{Ma}$. However, Sheth et al (2001) in their study of some trachytes in and around Bombay area provided ${ }^{40} \mathrm{Ar} /{ }^{39} \mathrm{Ar}$ ages of $60.4 \pm 0.6 \mathrm{Ma}$ and $61.8 \pm 0.6 \mathrm{Ma}$, ages that are considerably younger than peak of basaltic volcanism in Deccan. On the basis of these dates, Sheth et al 
(2001) argued that the total duration of volcanism in the Deccan, is $\sim 8 \mathrm{Ma}$ rather than $\sim 1 \mathrm{Ma}$ (Courtillot et al 1986).

In this section we also wish to address the following relevant questions pertaining to the petrogenesis of alkalic lavas from Kutch:

- Are the lavas in Kutch chemically different from their counterparts on other continents?

- What does the major element chemistry of lavas from Kutch indicate about the source?

Previous petrographic, major element, and trace element studies were most notably done by Krishnamurthy et al (1999). The authors also reported extensive zoning in the phenocrysts of olivine $(\mathrm{Ni}, \mathrm{Mg}$, and $\mathrm{Ca})$, clinopyroxene $(\mathrm{Ca}, \mathrm{Mg}$, $\mathrm{Al}$, and $\mathrm{Ti})$, and spinel $(\mathrm{Mg}, \mathrm{Cr}, \mathrm{Al}$, and $\mathrm{Ti})$. By plotting the bulk-rock major element composition of the lavas and the associated phenocrysts, these authors concluded that melanephelinites from Kutch were derived by olivine and eclogite fractionation in the mantle beneath Kutch. This conclusion was reached on the basis of depletion in $\mathrm{Al}_{2} \mathrm{O}_{3}$ and enrichment in trace elements. The probable parent(s) of these melanephelinites was proposed to be picritic liquid(s). Krishnamurthy et al (1999) further argued that basanites from the same area were also derived by fractional crystallization at some depth of olivine, clinopyroxene, and spinel. However, on the basis of major-element chemistry, Krishnamurthy et al (1999) argued that the bulkrock lavas represented primary magma compositions, and also invoked mixing of different parent magmas to explain some of the major and trace element compositions.

It is possible to introduce fractionation of olivine, cpx, and garnet to derive melanephelinites from picritic parental liquids. However, in that case the bulk-rock lava compositions, of Krishnamurthy et al (1999), cannot be treated as liquid compositions. In addition, lack of garnet either as a phenocryst or a xenocryst, precludes that such a conclusion to be drawn. Krishnamurthy et al (1999), did however, report an anomalous "garnet" composition. However, the composition of this "garnet" is so far removed from those reported in the xenolith literature, that the proposed fractionation of an eclogitic (cpx + garnet) assemblage cannot really be invoked on the basis of their finding. However, as pointed out by Krishnamurthy et al (1999) the combined fractionation of olivine and cpx can perhaps explain some major element compositions of the lavas considered in this paper. Instead of invoking crystal fractionation, an alternative explanation for the origin of silica-poor, mafic alkaline lavas in Kutch is to invoke partial melting of a carbonated mantle lher- zolite. In comparison with lavas from South Africa, Germany, and Freemans Cove, lavas from Kutch do not attain a high degree of undersaturation. However, as noted in the section on "Constraints from $\mathrm{CO}_{2}$-bearing experiments", lavas from Kutch can be derived from relatively advanced partial melting of a carbonated mantle lherzolite at pressures of 2.5-3 GPa (Hirose 1997; Gudfinnsson and Presnall 2003). In addition, the proposed fractionation of cpx from parental picritic liquids cannot be seen in the $\mathrm{CaO}-\mathrm{SiO}_{2}$ and $\mathrm{CaO} / \mathrm{Al}_{2} \mathrm{O}_{3}-\mathrm{SiO}_{2}$ variation diagrams (figures 5 and 6 ). However, olivine fractionation can perhaps explain some of the major elements $\left(\mathrm{SiO}_{2}-\mathrm{Mg} \#, \mathrm{CaO}-\mathrm{SiO}_{2}\right)$ discussed in this paper. Thus, on the basis of the above, we conclude that lavas from Kutch mainly represent partial melting of a carbonated mantle lherzolite, followed by olivine controlled fractionation, and magma mixing (as exemplified by moderate to severe zoning of crystals).

\section{Conclusions}

In order to understand the melting processes responsible for the generation of silica-poor, relatively mafic alkaline lavas, and also to clarify the role of garnet clinopyroxenite in the existing debate as a lithology controlling the major-element budget, we have discussed the major-element chemistry of these lavas at ocean islands and continental locations. On the basis of a few selected major elements, it appears that the partial melts of neither anhydrous lherzolite nor garnet pyroxenite have the potential to explain these variations. Partial melting of carbonated lherzolite, on the other hand, yields more plausible petrogenetic models for these lavas, and, in our view, is the most likely lithology to explain the majorelement chemistry of these lavas. In OIB locations, Samoan and Hawaiian lavas appear to record the minimum amount of melting of their respective source(s), followed closely by lavas from Gran Canaria and finally Polynesia. In continental locations, major-element chemistry indicates that lavas from South Africa (Sutherland and Saltpetre Kop) and Germany (Urach) experienced the least degree of melting of their source(s), followed by those from Texas, Hegau, Spiegel River, Robertson, and Eifel. Lavas from Deccan, Czech Republic, Oman, and Freemans Cove seem to be derived by the greatest amount of melting of their source(s). Importantly, a large variation in the lava compositions (especially $\mathrm{Mg} \#$ ), combined with moderate to severe zoning in the phenocryst phases also implies that very few (if any) of these bulk-rock lavas are direct mantle melts reflecting the condition in their source(s), and have undergone variable amounts of 
crystal fractionation or accumulation. In addition, most of the lavas considered here appear to require $\mathrm{CO}_{2}$ in their mantle sources.

\section{Acknowledgements}

The authors thank Hetu Sheth for his invitation to participate in this volume and providing reference material. Discussions on mantle petrology and magma genesis with Alex Corgne and Dean Presnall are gratefully acknowledged. Constructive official reviews by Michael Bizimis, Hetu Sheth, Andreas Stracke, and an anonymous reviewer helped us to provide a better-focused presentation. Michael Bizimis and Andreas Stracke provided especially penetrating and sometimes withering official reviews that are much appreciated, and SK also acknowledges earlier e-mail correspondence with Bizimis and Stracke. The authors are supported by Carnegie Institution of Washington and the US NSF grants to Jim Van Orman, Yingwei Fei, and Dean Presnall.

\section{References}

Barker D, Mitchell R H and McKay D 1987 Late Cretaceous nephelinite to phonolite magmatism in the Balcones Province, Texas; In: Mantle metasomatism and alkaline magmatism (eds) E Morris and J Pasteris Geological Society of America Special Publication No. 215 293-304

Basaltic Volcanism Study Project 1981: Basaltic volcanism on the terrestrial planets, (New York: Pergamon Press)

Basu A, Renne P R, Dasgupta D K, Teichmann F and Poreda R 1993 Early and late alkali igneous pulses and a high-3He plume origin for the Deccan Flood Basalts; Science 261 902-906

Biswas S K and Deshpande S V 1973 A note on the mode of eruption of the Deccan trap lavas with special reference to Kutch; J. Geol. Soc. India 14 134-143

Boctor N Z and Yoder H S 1986 Petrology of some melilitebearing rocks from Cape Province, Republic of South Africa: Relationship to Kimberlites; Am. J. Sci. 286 513-539

Canil D and Scarfe C M 1990 Phase relations in peridotite $+\mathrm{CO}_{2}$ systems to $12 \mathrm{GPa}$ : implications for the origin of kimberlite and carbonate stability in the Earth's upper mantle; J. Geophys. Res. 95 15805-15816

Clague D and Frey F 1982 Petrology and trace element geochemistry of the Honolulu Volcanics, Oahu; implications for the oceanic mantle below Hawaii; J. Petrol. 23 447-504

Clague D and Dalrymple G B 1987 The Hawaiian-Emperor volcanic chain, 1: Geologic evolution; U.S. Geol. Surv. Prof. Paper 1350 5-54

Clague D, Moore J, Dixon J and Friesen W 1995 Petrology of submarine lavas from Kilauea's Puna Ridge, Hawaii; J. Petrol. 36 299-349

Courtillot V, Besse J, Vandamme D, Montigny R, Jager J J and Capetta H 1986 Deccan flood basalts at the Cretaceous/Tertiary boundary?; Earth Planet. Sci. Lett. 80 $361-374$
Dalton J A and Presnall D C 1998a Carbonatitic melts along the solidus of model lherzolite in the system CaO$\mathrm{MgO}-\mathrm{Al}_{2} \mathrm{O}_{3}-\mathrm{SiO}_{2}-\mathrm{CO}_{2}$ from 3 to $7 \mathrm{GPa}$; Contrib. Mineral. Petrol. 131 123-135

Dalton J A and Presnall D C 1998b The continuum of primary carbonatitic-kimberlitic melt compositions in equilibrium with lherzolite: data from the system $\mathrm{CaO}-\mathrm{MgO}-\mathrm{Al}_{2} \mathrm{O}_{3}-\mathrm{SiO}_{2}-\mathrm{CO}_{2}$ at $6 \mathrm{GPa} ; J$. Petrol. 39 1953-1964

Duncan R A and Pyle D G 1988 Rapid eruption of the Deccan flood basalts at the Creataceous-Tertiary boundary; Nature 333 841-843

Dupuy C, Barsczus H, Dostal J, Vidal P and Liotard J 1989 Subducted and recycled lithosphere as the mantle source of ocean island basalts from southern Polynesia, Central Pacific; Chem. Geol. 114 477-489

Falloon T and Green D H 1989 The solidus of carbonated, fertile peridotite: Earth Planet. Sci. Lett. 94 364-370

Gudfinnsson G H and Presnall D C 1996 Melting relations of model lherzolite in the system $\mathrm{CaO}-\mathrm{MgO}-\mathrm{Al}_{2} \mathrm{O}_{3}-\mathrm{SiO}_{2}$ at 2.4-3.4 GPa and the generation of komatiites; J. Geophys. Res. 101 27701-27709

Gudfinnsson G H and Presnall D C 2000 Melting behaviour of model lherzolite in the system $\mathrm{CaO}-\mathrm{MgO}-\mathrm{Al}_{2} \mathrm{O}_{3}-\mathrm{SiO}_{2}-$ $\mathrm{FeO}$ at 0.7-2.8 GPa; J. Petrol. 41 1241-1269

Gudfinnsson G H and Presnall D C 2003 Continuous gradations among primary kimberlitic, carbonatitic, melilititic, and komatiitic melts in equilibrium with garnet lherzolite at 3-8 GPa; Proc. 8th Int. Kimber. Conf. Extended abstracts

Hegner E, Walter H and Satir M 1995 Pb-Sr-Nd isotopic compositions and trace element geochemistry of megacrysts and melilitites from the Tertiary Urach volcanic field; source composition of small volume melts under SW Germany; Contrib. Mineral. Petrol. 122 322-335

Hirose K and Kushiro I 1993 Partial melting of dry peridotites at high pressures: determination of compositions of melts segregated from peridotite using aggregates of diamond; Earth Planet. Sci. Lett. 114 477-489

Hirose K 1997 Partial melt compositions of carbonated peridotite at $3 \mathrm{GPa}$ and the role of $\mathrm{CO}_{2}$ in alkali-basalt magma generation; Geophys. Res. Lett. 24 2837-2840

Hirschmann M M, Kogiso T, Baker M and Stolper E M 2003 Alkalic magmas generated by partial melting of garnet pyroxenite; Geology 31 481-484

Hoernle K and Schmincke H U 1993 The petrology of the tholeiites through melilite nephelinites on Gran Canaria, Canary Islands; crystal fractionation, accumulation, and depths of melting; J. Petrol. 34 573-597

Janney P, Le Roex A P, Carlson R W and Viljoen K S 2002 A chemical and multi-isotope study of the Western Cape olivine melilitite province, South Africa; implications for the sources of kimberlites and the origin of the HIMU signature in Africa; J. Petrol. 43 2339-2370

Kaila K L, Reddy P R and Dixit M N 1981 Deep crustal structure at Koyna indicated by deep seismic soundings; J. Geol. Soc. India 22 1-16

Karmalkar N, Griffin W L and O'Reilly S 2000 Ultramafic xenoliths from Kutch, Northwest India: plume-related mantle samples?; Int. Geol. Rev. 42 416-444

Keshav S, Gudfinnsson G H, Sen G, Presnall D C and Fei Y 2003a Tholeiitic to alkalic transition in basaltic liquids: some inferences from high-pressure garnet-pyroxenite melting; Annual V.M. Goldschmidt Conference, Japan

Keshav S, Gudfinnsson G H, Sen G, Presnall D C and Fei Y 2003b Ocean-island lavas: garnet clinopyroxenite or $\mathrm{CO}_{2}$ bearing mantle lherzolite?; Trans. Am. Geophys. Union (Fall Meeting) 
Keshav S, Gudfinnsson G H, Sen G and Fei Y 2004 Highpressure melting experiments on garnet clinopyroxenite and the alkalic to tholeiitic transition in ocean island basalts; Earth Planet. Sci. Lett. 223 365-379

Kogiso T, Hirose K and Takahashi E 1998 Melting experiments on homogeneous mixtures of peridotite and basalt; application to the genesis of ocean island basalts; Earth Planet. Sci. Lett. 162 45-61

Kogiso T, Hirschmann M M and Frost D J 2003 Highpressure partial melting of garnet pyroxenite: possible mafic lithologies in the source of ocean island basalts; Earth Planet. Sci. Lett. 216 603-617

Krishnamurthy P, Pande K, Gopalan K and MacDougall J D 1999 Mineralogical and chemical studies on alkaline basaltic rocks of Kutch, Gujarat, India; Mem. Geol. Soc. India 43 757-783

Maaloe S, Dodie J, Smedley P, Svend P and Garmann L 1992 The Koloa volcanic suite of Kauai, Hawaii; J. Petrol. 33 761-784

Milholland C S and Presnall D C 1998 Liquidus phase relations in $\mathrm{CaO}-\mathrm{MgO}-\mathrm{Al}_{2} \mathrm{O}_{3}-\mathrm{SiO}_{2}$ system at $3.0 \mathrm{GPa}$ : the aluminous pyroxene thermal divide and high-pressure fractionation of picritic and komatiitic magmas; J. Petrol. 38 3-27

Mitchell R H and Platt R G 1984 The Freemans Cove volcanic suite; field relations, petrochemistry, and tectonic setting of nephelinite-basanite volcanism associated with rifting in the Canadian Arctic Archipelago; Can. J. Earth Sci. 21 428-436

Natland J and Hawkins J 1975 Nephelinites and basanites of the Samoan linear volcanic chain: their possible tectonic significance; Earth Planet. Sci. Lett. 24 427-439

Norton I O and Sclater J G 1979 A model for the evolution of Indian Ocean and the break of Gondwanaland; J. Geophys. Res. 84 6803-6830

Pande K, Venkatesan T R, Gopalan K, Krishnamurthy P and MacDougall I $1989{ }^{40} \mathrm{Ar} /{ }^{39} \mathrm{Ar}$ ages of alkali basalts from Kutch, Deccan volcanic province; Geol. Soc. India Spec Pub. No. 10 145-150

Reiners P and Nelson B 1998 Temporal-compositionalisotopic trends in rejuvenated- stage magmas of Kauai, Hawaii, and implications for mantle melting processes; Geochim. Cosmochim. Acta 62 2347-2368
Ryabchikov I, Brey G and Bulatov V 1993 Carbonate melts coexisting with mantle peridotite at $50 \mathrm{kbar}$; Petrology $\mathbf{1}$ 189-194

Sclater J G and Fisher R L 1974 Evolution of the east central Indian Ocean with emphasis on the tectonic setting of the Ninetyeast Ridge; Geol. Soc. Am. Bull. 85 683-702

Sheth H C, Pande K and Gopalan K $2001{ }^{40} \mathrm{Ar}-{ }^{39} \mathrm{Ar}$ ages of Bombay trachytes: evidence for a Paleocene phase of Deccan volcanism; Geophys. Res. Lett. 28 3513-3516

Stracke A, Salters V J M and Sims K W W 1999 Assessing the presence of garnet pyroxenite in the mantle sources of basalts through combined hafniumneodymium-thorium isotope systematics; Geochem. Geophys. Geosys. 1 1999GC000013

Vaneckova M, Holub F, Soucek J and Bowes D 1993 Geochemistry and petrogenesis of the Tertiary alkaline volcanic suite of the Labe tectono-volcanic zone, Czech Republic; Mineral. Petrol. 48 17-34

Venkatesan T R, Pande K and Gopalan K $1986{ }^{40} \mathrm{Ar}-{ }^{39} \mathrm{Ar}$ dating of Deccan basalts; J. Geol. Soc. India $\mathbf{2 7}$ 102-109

Walter M J and Presnall D C 1994 Melting behaviour of simplified lherzolite in the system $\mathrm{CaO}-\mathrm{MgO}-\mathrm{Al}_{2} \mathrm{O}_{3}-\mathrm{SiO}_{2}-$ $\mathrm{Na}_{2} \mathrm{O}$ from 7 to 35 kbar; J. Petrol. 35 329-359

Walter M J 1998 Melting of garnet peridotite and the origin of komatiite and depleted lithosphere; J. Petrol. 39 $29-60$

Watts A B and Cox K G 1989 The Deccan Trap: An interpretation in terms of progressive lithospheric flexure in response to migrating lode; Earth Planet. Sci. Lett. 93 85-97

Wedepohl K H, Gohn E and Hartmann G 1994 Cenozoic alkali basaltic magmas of western Germany and their products of differentiation; Contrib. Mineral. Petrol. 115 253-278

Wilson M and Downes H 1991 Tertiary-Quaternary extension-related alkaline magmatism in Western and Central Europe; J. Petrol. 32 811-849

Wilson M, Rosenbaum J and Dunworth D 1995 Melilitites; partial melts of the thermal boundary layer? Contrib. Mineral. Petrol. 119 181-196

Zindler A and Hart S R 1986 Chemical geodynamics; Ann. Rev. Earth Planet. Sci. 14 496-571 